\title{
MESTRE OSCAR SANTOS E O TERRITÓRIO FEDERAL DO AMAPÁ: UM PROJETO INTELECTUAL DEDICADO AO ENSINO DE MÚSICA EM MACAPÁ NO SÉCULO XX
}

\author{
VITOR SOUSA CUNHA NERY*
}

Resumo: O artigo analisa a atuação do Mestre Oscar Santos, no ensino de música no Território Federal do Amapá, no século XX e a sua constituição enquanto um intelectual amazônico. Compreender as formas de pensar e agir dos intelectuais/professores como, Oscar Santos, com base em um contexto histórico e cultural específico que se constituem como problema que pode ser situado nos domínios da história da educação em diálogo com as contribuições de uma nova história intelectual. Utilizou-se como fonte de pesquisa a biografia de Oscar Santos, escrita pela sua neta Lúcia Uchôa, fotografias, notícias de jornais e blogs disponíveis na internet. Apresenta-se a trajetória de vida do Mestre Oscar Santos, destacando os itinerários de formação, as redes de sociabilidade e a sua geração. No Território Federal do Amapá, Oscar Santos, transformou-se num grande educador musical e tornou-se o responsável pela Academia de Música Oscar Santos, onde formou várias gerações de músicos que tocam em bandas e tornou-se mestre e maestro das primeiras bandas do Amapá e da Orquestra Oscar Santos, de onde saíram os primeiros conjuntos musicais do Amapá. Mestre Oscar construiu seu projeto intelectual na troca de experiências e amizades com grandes personalidades da música e cultura da sua geração, como por exemplo, Bruno de Menezes, José Plácido Gonçalves, Mario Mascarenhas e Altamiro Carrilho. Mestre Oscar Santos contribuiu também na formação de uma nova geração de músicos que seguiram carreira militar. E outros que seguiram a carreira docente, e atuam em instituições renomadas de ensino de música pelo Brasil.

Palavras-Chave: Oscar Santos. Intelectual. Território Federal do Amapá.

\section{Master Oscar Santos and the federal territory of Amapá: an intellectual project dedicated to music education in Macapá in the twentieth century}

Abstract: the article analyzes the performance of Mestre Oscar Santos in the teaching of music in the Federal Territory of Amapá in the 20th century and his constitution as an Amazonian intellectual. It understands the ways of thinking and acting of intellectuals / teachers such as Oscar Santos, based on a specific historical and cultural context that constitute a problem that can be situated in the domains of the history of education in dialogue with the contributions of a new history intellectual. The biography of Oscar Santos, written by his granddaughter Lúcia Uchôa, photographs, news stories and blogs available on internet networks was used as research source. It presents the life trajectory of Master Oscar Santos, highlighting the training itineraries, the networks of sociability and their generation. In the Federal Territory of Amapá, Oscar Santos, became a great musical educator and became the head of the Academy of Music

\footnotetext{
* Doutorando em Educação na Universidade Federal do Pará (UFPA). Professor do Curso de Pedagogia da Universidade do Estado do Amapá (UEAP).
} 
Oscar Santos, where he formed several generations of musicians who play in bands and became master and conductor of the first bands of the Amapá and the Oscar Santos Orchestra, from where the first musical groups of Amapá left. Master Oscar, built his intellectual project in the exchange of experiences and friendships with great personalities of the music and culture of his generation, such as Bruno de Menezes, José Plácido Gonçalves, Mario Mascarenhas and Altamiro Carrilho. Master Oscar Santos, also contributed to the formation of a new generation of musicians who followed a military career. And others who followed the teaching career, and work in renowned music education institutions throughout Brazil.

Keywords: Oscar Santos. Intellectual. Federal Territory of Amapá.

\section{Introdução}

Este artigo tem como objetivo analisar a atuação do Mestre Oscar Santos, no ensino de música no Território Federal do Amapá, no século XX e a sua constituição enquanto um intelectual amazônico. Utiliza-se a abordagem da História intelectual, um campo histórico autônomo que, longe de se fechar sobre si mesmo, é um campo aberto situado no cruzamento das histórias políticas, social e cultural (Sirineli, 2003, p. 232).

Esse campo é recente e renovado na retomada da "Nova História Política" na década de 1870 , no qual a problemática política e do poder não é mais restrita aos domínios do Estado, uma vez que investiga a natureza social e cultural do poder político inserido nas contradições e antagonismos da sociedade civil. Modificou seu objeto de estudo, produzindo desdobramentos da ação política em termos de práticas discursivas, instituições, partidos, eleições, manifestações, opinião pública, guerra, mídia, associações etc. Transformou seus postulados metodológicos, ao incorporar múltiplas temporalidades históricas, estabelecendo o diálogo com outras disciplinas, como a antropologia e ciência política; adotando novos aportes conceituais, como micropoderes e cultura, representações, imaginário, etc. (Rémond, 2003).

A História Intelectual investe-se, deste modo, na relação entre o plano subjetivo dos sentidos e o plano objetivo das práticas sociais, encaminha-se, por sua vez, no exame dos procedimentos de produção, circulação e recepção de ideias e discursos políticos, científicos, pedagógicos ou artísticos que ultrapassam a lógica e método de análise internalista (de conteúdo) que caracterizou por muito tempo a história das 
ideias (Vieira, 2008; Zanotto, 2008).

Sirinelli (2003, p. 242) entende o intelectual por meio de duas definições: "uma ampla e sociocultural, englobando os criadores e mediadores culturais, e a outra mais estreita, baseada na noção de engajamento [...] na vida da cidade como ator". Assim, o autor inclui na primeira acepção os escritores, jornalistas e professores, bem como os criadores e mediadores em potencial, como por exemplo, os estudantes. Na segunda acepção estaria localizado um grupo mais restrito, composto por indivíduos que exercem uma atividade de maior influência no cenário público por defenderem uma concepção ideológica ou uma causa de impacto social. Essa função é exercida mediante a utilização de certa especialidade de saberes, que permite uma ação mais incisiva na esfera social, bem como o reconhecimento da sociedade em que está inserido, como atuante na vida da cidade como um ator social. Além disso, "tal acepção não é, no fundo, autônoma da anterior, já que são dois elementos de natureza sociocultural" (Sirinelli, 2003, p. 243).

Nessa perspectiva compreende-se o Mestre Oscar Santos enquanto um intelectual amazônico no que se refere ao ensino de Música no Território Federal do Amapá no século XX. As formas de pensar e agir dos intelectuais/professores, como Oscar Santos, com base em um contexto histórico e cultural específico, constituem-se como problema que pode ser situado nos domínios da história da educação em diálogo com as contribuições de uma nova história intelectual.

A história intelectual da educação pode ser compreendida dentro do domínio e da abordagem da história da educação. A investigação sobre pensamentos e ações de intelectuais no âmbito da história da educação pressupõe a análise do percurso percorrido pelo ator social em questão da defesa de seus projetos e práticas para o progresso do campo educacional, sendo importante a apreciação de suas bases teóricas que se referem à formação humana e social. A pesquisa que tem como finalidade o estudo dos intelectuais,

[...] é uma perspectiva que objetiva estabelecer os nexos, as relações entre os intelectuais, as correntes de pensamento e o seu meio social. Investigamos os intelectuais porque consideramos que as suas ideias e as suas trajetórias são testemunhos privilegiados dos diversos projetos formativos que demarcam as disputas em torno da direção dos processos de formação das novas gerações (Vieira, 2001, p. 55). 
Desse modo, o estudo sobre intelectuais na história da educação pressupõe a análise do grupo social a qual pertence e do grupo social a qual representa, bem como dos movimentos sociais e educacionais que participou e das relações que estabeleceu com o Estado e sociedade. Gramsci (2004) assevera que os intelectuais são, na sociedade, representantes de classes, eles intervêm nos episódios da cultura, o indivíduo organiza e sustenta a estrutura social e tem a capacidade de refletir sobre si mesmo e sobre sua relação com a sociedade.

Compreender como historicamente vem se expressando as ideias e ações dos agentes da educação tem sido uma prática desenvolvida no contexto da escrita da história da educação ao longo de décadas. A história intelectual em diversos momentos se aproximou da história das ideias (Falcon, 1997), da história cultural, da história social das ideias e da história política. Isso porque investigar a expressão do pensamento pedagógico de determinado intelectual exige a compreensão da conjuntura social, que envolve aspectos culturais, ideológicos e políticos, os quais embasam sua prática. Nesse diálogo que Giroux (1992) defende o professor como um intelectual transformador, "o inovador cultural, criador de condições que estimulem e implementem novas práticas sociais visualizando um futuro promissor e realizável".

Fundamentando-se nas orientações de Sirinelli (2003) apresenta-se a seguir a trajetória de vida do Mestre Oscar Santos, destacando os itinerários de formação, as redes de sociabilidade e a sua geração. A observação dos itinerários de formação dos intelectuais revela o engajamento deles, enquanto o estudo das redes de sociabilidade demonstra as ideologias e a cultura política produzida numa determinada época ou que foram veiculadas pelos intelectuais em dado momento; já o enfoque na noção de geração está relacionado com as solidariedades estabelecidas entre os intelectuais, a partir de um marco que os diferencie dos intelectuais de outro grupo.

\section{Itinerário Do Mestre Oscar Santos}

A construção de itinerários considera a família, o meio social de origem, o grupo de pertencimento, assim como as adesões temporárias ou duradouras dos intelectuais, pois compõe o processo de tornar-se intelectual. As "vivências cotidianas, que marcam a sensibilidade, as escolhas, as afinidades, as aproximações e os deslocamen- 
tos que conformam o desenho da trajetória intelectual” (ALVES, 2012, p.116).

De acordo com Araújo (2011, p.11), intelectuais como Oscar Santos, construíram e divulgaram, por meio de suas capacidades de compreensão do mundo, se valendo de um instrumental importante (no caso de Oscar Santos, o ensino de música) e do prestígio que tinham junto ao poder constituído e movimentos populares, suas representações acerca das condições as quais se encontravam as populações mais empobrecidas, não por acaso também mestiças, e do lugar que deveria a educação ocupar para superação desse estado.

Assim, analisar o pensamento desse intelectual é uma forma de tornar audível uma voz que, apesar de estar em diálogo constante com o seu tempo, a história silenciou. Na busca de 'escutar' essa voz, e corroborar a história do pensamento social sobre ensino de música na Amazônia, é nosso propósito fazer a escrita da história partindo da compreensão de que um intelectual é constituído por tudo o que lhe sucede no decorrer de sua vida, de forma que as vivências cotidianas, que marcam a sensibilidade, as escolhas, as afinidades, as aproximações e os deslocamentos que conformam o desenho da trajetória intelectual. Nessa trajetória ele é tomado como indivíduo inserido em múltiplas dimensões espaços-temporais (Alves, 2012, p. 116).

O itinerário do Mestre Oscar Santos, segundo a biografia escrita por sua neta Lúcia Uchôa (2003), inicia no Pará no município de Abaetetuba em 29 de dezembro de 1905. Os pais do Mestre Oscar eram Alípio Manoel dos Santos e Isolina Marinho dos Santos. Ele era o filho mais velho e tinha mais 04 irmãos, a saber: Teodolina, Anésia, Veríssimo e Raimunda. Desde criança sempre teve contato com a música através de seu pai que era Músico de banda e dono de um conjunto musical, após a morte de seu pai, Oscar Santos passou a morar com o seu padrinho, Oscar Solano, que também era músico e assim, ele começou os primeiros passos na música.

Durante a infância, Oscar Santos foi impedido por seu o avô de manusear os instrumentos musicais deixados pelo seu pai, diante dessa situação fez uma promessa que um dia iria aprender a ler as notas musicais que seu pai tocava e teria a sua própria banda. Aos sete anos de idade após ter sido inserido no mundo musical pelo seu padrinho, Oscar Solano, pediu ajuda a um casal de vizinhos músicos, para que lhe dessem aulas, porque queria aprender a tocar vários instrumentos musicais de qualquer maneira, desde então passou a se dedicar aos livros de música que seus vizinhos lhe 
emprestavam (UchôA, 2003).

Segundo Elias (1995, p.145), para se compreender alguém é preciso conhecer os anseios primordiais que este deseja satisfazer. A vida faz sentido ou não para as pessoas, dependendo da medida em que elas conseguem realizar tais aspirações, mas os anseios não estão definidos antes de todas as experiências. Desde os primeiros anos de vida, os desejos vão evoluindo, ao longo dos anos, na forma determinada pelo curso da vida. E nem sempre cabe à pessoa decidir se seus desejos serão satisfeitos, ou até que ponto o serão, já que sempre eles estão dirigidos para outros, para o meio social.

Com dificuldades financeiras, Oscar Santos só estudou até o curso primário, diante disso ocupava o seu tempo com o estudo da música. Aos quatorze anos Santos passou a ter aulas de música com o Mestre Laudelino ${ }^{1}$ e o maestro Raimundo Pauxis ${ }^{2}$, ambos da Banda de Música Carlos Gomes ${ }^{3}$, onde aprendeu a tocar o instrumento de sopro Bombardino. Em pouco tempo precisou trocar de instrumento, pois o bocal dos instrumentos de sopro feria seus lábios e então passou para percussão e bateria. Aprendeu a tocar Bateria e aos dezessete anos passou a integrar o Conjunto Euterpe Jazz como Baterista (UCHÔA, 2003).

\footnotetext{
${ }^{1}$ Laudelino Nunes Fernandes nasceu no Rio Guajará de Beja, era professor escolar, músico que tocava bombardino, professor de música e maestro. Inicialmente, a família do Mestre Laudelino morou em Igarapé-Miry e posteriormente em Abaetetuba, onde tocava na banda Carlos Gomes.

${ }^{2}$ Raimundo Pauxis, filho do fundador da banda Carlos Gomes, também ficou famoso na cidade de Abaetetuba, como mestre de banda.

${ }^{3}$ A Banda Carlos Gomes foi criada junto com o clube musical Carlos Gomes, fundada em 25/04/1880, na cidade de Abaetetuba-Pa, pelo Maestro Hermínio Pauxis, tocava na festa do Padroeiro, o Santo São Raimundo Nonato, clube do qual era o Patrono e que promovia as antigas festas desse Santo no antigo 'Arraial do Divino Espírito Santo', na Capela do Divino.
} 
Fotografia 1: Banda Euterpe Jazz, na Praça Matriz- Macapá-AP.

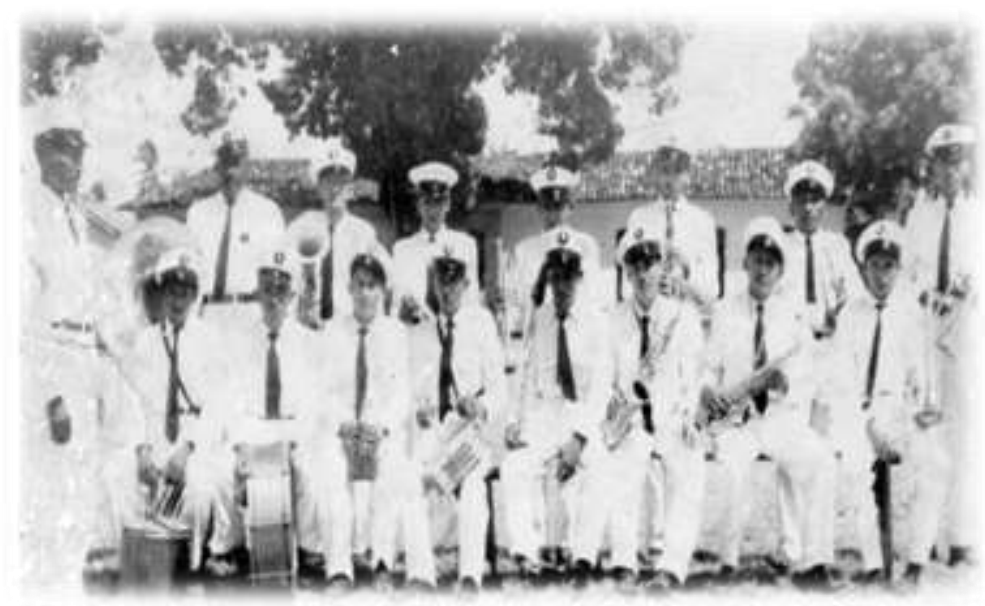

Fonte: Site Porta Retrato AP (2018).

Durante a adolescência, Oscar Santos já ministrava aulas particulares de música, ofício que fazia com muito prazer, pois era uma das atividades que mais gostava de desenvolver. Em contato com o gênero musical Jazz e participando da Banda Euterpe, o músico começou a adquirir experiências e aprendeu a tocar novos instrumentos de sopro como o saxofone, flauta transversal e clarineta. Na década de 1930, Oscar Santos realizou diversas viagens para os municípios do interior do Estado do Pará, dentre eles Macapá, onde formou bandas e pequenos grupos musicais (Uchôa, 2003).

Para Lopes (2003, p.41) o que caracteriza um intelectual, segundo os pressupostos da

História Intelectual, é que ele tenha "adquirido notoriedade colocando seus dotes de retórica e seu prestigio pessoal a serviço do bem-estar de seus compatriotas [...]. E, além disso, o fato de se bater na defesa de valores universais como a verdade e a justiça". Nesse caso entendemos Oscar Santos como intelectual, pois utilizou o seu conhecimento musical para formar bandas pelos interiores da Amazônia, levando perspectiva de futuro para jovens e adultos, principalmente aos mais pobres que não tinham representação, característica que Said (2005) aponta como típica dos intelectuais.

É preciso esclarecer que o intelectual, para agir, não precisa ser comissionado, pois "é próprio do ofício do intelectual arvorar-se em defesa dos valores transcendentes para a sociedade. Por outro lado, essa defesa se assume sem que, para tanto, receba necessariamente algum mandato da sociedade" (Gonzalez, 2001, p.119), de tal forma que o intelectual pode ser caracterizado "como um exilado e marginal, como 
amador e autor de uma linguagem que tenta falar a verdade ao poder" (Said, 2005, p. 15), tornando-se "uma espécie de memória alternativa, que exponha seu próprio discurso alternativo, que não permita que a consciência ignore a realidade ou fique adormecida" (Said, 2003, p. 40), o que faz dele um outsider, um perturbador do status quo (Said, 2005).

Na sua trajetória de músico, Oscar Santos desenvolveu a habilidade de compositor, pois escreveu mais de 130 arranjos musicais durante sua carreira, conforme se visualiza no quadro 1, assim tornou-se um dos maiores compositores de dobrados do Brasil.

\section{Quadro 1- Catálogo das Obras do Mestre Oscar Santos}

\begin{tabular}{|c|c|c|c|c|}
\hline № & TÍTULO & GÊNERO & LOCAL/DATA & OBSERVAÇÃO \\
\hline 1 & 15 de Maio & Dobrado & Macapá/ 1943 & Arranjo para Banda \\
\hline 2 & 19 de Agosto & Dobrado & Macapá /1946 & Arranjo para Banda \\
\hline 3 & Centenário de Macapá & Dobrado & Macapá/ 1957 & Arranjo para Banda \\
\hline 4 & 24 de Junho & Dobrado & Soure/ 1937 & Arranjo para Banda \\
\hline 5 & 24 de Maio & Dobrado & & Arranjo para Banda \\
\hline 6 & 29 de Dezembro & Dobrado & Chaves/1940 & Arranjo para Banda \\
\hline 7 & Aluízio Cunha & Dobrado & Soure/ 1938 & Arranjo para Banda \\
\hline 8 & Antônio Dias & Dobrado & Chaves/ 1941 & Arranjo para Banda \\
\hline 9 & Aprendizes & Dobrado & Macapá & Coleção Colegial \\
\hline 10 & Capitão Euclides Rodrigues & Dobrado & Macapá/1962 & Arranjo para Banda \\
\hline 11 & Coronel Arlindo Cacella & Dobrado & Chaves/1940 & Arranjo para Banda \\
\hline 12 & Dobrado 15 & Dobrado & Soure/1938 & Arranjo para Banda \\
\hline 13 & Dobrado Centro Musical & Dobrado & & Arranjo para Banda \\
\hline 14 & Dobrado Oscar Santo & Dobrado & Macapá/ 1968 & Arranjo para Banda \\
\hline 15 & Dobrado Mariano Antunes & Dobrado & & Arranjo para Banda \\
\hline 16 & Dobrado $n \div 1$ & Dobrado & Macapá/1963 & Coleção Colegial \\
\hline 17 & $\begin{array}{c}\text { Dobrado no } 2 \\
\text { Prof. Alzir Maia }\end{array}$ & Dobrado & Macapá/1963 & Coleção Colegial \\
\hline 18 & Dobrado $n=3$ & Dobrado & Macapá/1963 & Coleção Colegial \\
\hline 19 & Dobrado $n \circ 4$ & Dobrado & Macapá & Coleção Colegial \\
\hline 20 & Dobrado $n \div 5$ & Dobrado & Macapá & Coleção Colegial \\
\hline 21 & Dobrado no 6 & Dobrado & Macapá/1967 & Coleção Colegial \\
\hline 22 & Edmundo Pamplona & Dobrado & Soure/1938 & Arranjo para Banda \\
\hline 23 & Dobrado para Principiante & Dobrado & Macapá/1974 & Arranjo para Banda \\
\hline 24 & Epifânio Martins & Dobrado & Macapá/1965 & Coleção Colegial \\
\hline 25 & Está Gravado & Dobrado & Chaves/1940 & Arranjo para Banda \\
\hline 26 & General Manuel Rabello & Dobrado & & $\begin{array}{c}\text { Arr. 10 Trompete } \\
\text { (Incp) }\end{array}$ \\
\hline 27 & João Olinto & Dobrado & Chaves/1940 & Arranjo para Banda \\
\hline 28 & João Santos & Dobrado & Macapá/ 1963 & Arranjo para Banda \\
\hline 29 & Lauro Mácola & Dobrado & Chaves/1935 & Arranjo para Banda \\
\hline 30 & Lauro Neri & Dobrado & Chaves/1941 & Arranjo para Banda \\
\hline 31 & Leôncio Gonçalves & Dobrado & Macapá/1948 & Arranjo para Banda \\
\hline 32 & Major Lourival Benvenuto & Dobrado & Macapá/1969 & Arranjo para Banda \\
\hline
\end{tabular}




\begin{tabular}{|c|c|c|c|c|}
\hline 33 & O 10 Semestre & Dobrado & Macapá/1971 & Coleção Colegial \\
\hline 34 & O 2o Semestre & Dobrado & Macapá/1971 & Coleção Colegial \\
\hline 35 & Os Bonequinhos & Dobrado & Macapá/1966 & Coleção Colegial \\
\hline 36 & Prudente Araújo & Dobrado & Macapá/1956 & Arranjo para Banda \\
\hline 37 & Recordação dos 17 & Dobrado & Macapá/1958 & Arranjo para Banda \\
\hline 38 & Rodolpho Chermont & Dobrado & Chaves/ 1941 & Arranjo para Banda \\
\hline 39 & Rujão & Dobrado & Chaves/1940 & Arranjo para Banda \\
\hline 40 & Salvaterra & Dobrado & Soure/1937 & Arranjo para Banda \\
\hline 41 & $\begin{array}{c}\text { Sandoval Santos } \\
\text { Homenagem ao Filho }\end{array}$ & Dobrado & Chaves/1941 & Arranjo para Banda \\
\hline 42 & Santino Rodrigues & Dobrado & Macapá/1963 & Arranjo para Banda \\
\hline 43 & Sargento Rosivaldo & Dobrado & Macapá/1965 & Arranjo para Banda \\
\hline 44 & Sente o Nome & Dobrado & Macapá 1949 & Arranjo para Banda \\
\hline 45 & Soldados Brasileiros & Dobrado & Macapá/1962 & Arranjo para Banda \\
\hline 46 & Ana Maria & Valsa & Macapá & $\begin{array}{c}\text { Arranjo para Acorde- } \\
\text { on } \\
\end{array}$ \\
\hline 47 & Áurea & Valsa & Salvaterra/ 1942 & Arr. 10 Trompete $\mathrm{Bb}$ \\
\hline 48 & Conceição & Valsa & Macapá/1958 & $\begin{array}{c}\text { Arranjo para Acorde- } \\
\text { on }\end{array}$ \\
\hline 49 & Horizontina & Valsa & Macapá/1963 & Arranjo para Violino \\
\hline 50 & Mãezinha Querida & Valsa & Macapá/1961 & $\begin{array}{c}\text { Arranjo para Acorde- } \\
\text { on }\end{array}$ \\
\hline 51 & Pensando em Ti & Valsa & Chaves/1942 & Arr. Trombone (Inc) \\
\hline 52 & Quando o Amor Passa & Valsa & Macapá/ 1949 & Arranjo para Banda \\
\hline 53 & Recordação & Valsa & Macapá/1952 & Enviado à São Paulo* \\
\hline 54 & Reminiscências & Valsa & Chaves/ 1941 & Arranjo para Banda \\
\hline 55 & Ruy Barbosa & Valsa & & $\begin{array}{c}\text { Arranjo para acorde- } \\
\text { on }\end{array}$ \\
\hline 56 & Saudades da Viçosa & Valsa & Viçosa/ 1934 & Arranjo para Banda \\
\hline 57 & Valsa no1 & Valsa & Macapá/ 1949 & Arranjo para Banda \\
\hline 58 & Valsa & Valsa & Macapá/1968 & \\
\hline 59 & Valsa & Valsa & Macapá/1974 & \\
\hline 60 & Valsa de Oscar Santos & Valsa & Macapá/1973 & \\
\hline 61 & Valsa Iracy & Valsa & Macapá/1959 & Arranjo p/ Acordeon \\
\hline 62 & Valsa Neuma Santos & Valsa & Soure/1938 & Homenagem à filha \\
\hline 63 & Neusa & Valsa & Macapá/1962 & \\
\hline 64 & Valsa Olásia Santos & Valsa & Chaves/1939 & Homenagem à filha \\
\hline 65 & Valsa & Valsa & Macapá/1973 & Sax. Tenor \\
\hline 66 & Pensando em Ti & Valsa & Chaves/1942 & Arranjo para Banda \\
\hline 67 & Lundú & Lundú & Macapá/1965 & Arranjo p/ Flautim \\
\hline 68 & Eu vou me Rebolar & Marcha & Macapá/1965 & Marcha carnavalesca \\
\hline 69 & Marchinha & Marcha & Macapá/1972 & Arranjo $\mathrm{p} /$ Banda \\
\hline 70 & Chegou o Dia & Marcha & Macapá/1955 & \\
\hline 71 & Canção do América Futebol Clube & Marcha & Macapá/1957 & Arranjo $\mathrm{p} / \mathrm{Banda}$ \\
\hline 72 & Canção do Clube 4 -S & Marcha & Macapá/1967 & Arranjo p/ Banda \\
\hline 73 & Canção dos 30 Anos do Amapá & Marcha & Macapá & Arranjo $\mathrm{p} / \mathrm{Banda}$ \\
\hline 74 & 23 de Abril & Marcha & Macapá/1963 & Arranjo p/ Banda \\
\hline 75 & Bodas de Prata & Marcha & Macapá/1974 & Arranjo p/ Banda \\
\hline 76 & Gonçalves Dias & Marcha & Chaves/ 1941 & Arranjo $\mathrm{p} / \mathrm{Banda}$ \\
\hline 77 & Homenagem ao Dias das Mães & Marcha & & \\
\hline 78 & Isso é Conversa & Marcha & Macapá/ 1953 & Marcha carnavalesca \\
\hline 79 & Mamãe Minha Querida & Marcha & Macapá & Arranjo p/ Banda \\
\hline 80 & Marcha de Rua & Marcha & Macapá & Cordão do Curió \\
\hline 81 & Marcha N.1 & Marcha & Macapá & Arranjo p/ Banda \\
\hline
\end{tabular}




\begin{tabular}{|c|c|c|c|c|}
\hline 82 & Marcha N.2 & Marcha & Macapá/1967 & Arranjo $\mathrm{p} / \mathrm{Banda}$ \\
\hline 83 & Marcha N.6 & Marcha & Macapá/1972 & $\begin{array}{l}\text { Arranjo } \mathrm{p} / \text { Banda } \\
\text { Para principiantes }\end{array}$ \\
\hline 84 & Marcha Oscar Santos & Marcha & Macapá/1948 & Arranjo $\mathrm{p} / \mathrm{Banda}$ \\
\hline 85 & $\begin{array}{c}\text { Marcha } p / \text { Senhorita } \\
\text { Aninha }\end{array}$ & Marcha & Macapá/1957 & Arranjo p/ Banda \\
\hline 86 & Marcha p/Acordeon & Marcha & Macapá & Arranjo p/ Acordeon \\
\hline 87 & Marcha Santa Cecília & Marcha & Macapá/1949 & Arranjo p/ Banda \\
\hline 88 & Marcha Solene 16 de Fevereiro. & Marcha & Chaves/ 1941 & Arranjo $\mathrm{p} / \mathrm{Banda}$ \\
\hline 89 & No Jeepe do João & Marcha & Macapá/1953 & Marcha Carnavalesca \\
\hline 90 & O Meu Primor & Marcha & Macapá/ 1972 & Arranjo p/ Banda \\
\hline 91 & Uniforme Azul & Marcha & Macapá/1972 & Arranjo $\mathrm{p} / \mathrm{Banda}$ \\
\hline 92 & Teu Nome & Marcha & Macapá/ 1953 & Marcha carnavalesca \\
\hline 93 & Marcha 2 de abril & Marcha & Chaves/1940 & Arranjo para Banda \\
\hline 94 & Eu Não Sei Nada & Maxixe & Macapá/1966 & Arranjo p/ Banda \\
\hline 95 & Hino a Jesus & Religioso & Macapá/ 1961 & \\
\hline 96 & Hino a N.S. do Perp. Socorro & Religioso & Macapá/ 1963 & Arranjo para Banda \\
\hline 97 & Ladainha de N.S. da Conceição & Religioso & Macapá/ 1947 & \\
\hline 98 & Ladainha $n$ o 7 & Religioso & Chaves/ 1939 & \\
\hline 99 & Mater Puríssima & Religioso & Abaetetuba 1935 & $\begin{array}{c}\text { Letra de Bruno de } \\
\text { Menezes } \\
\text { Arranjo } \mathrm{p} / \text { banda }\end{array}$ \\
\hline 100 & $\begin{array}{c}\text { Missa Solene à N. Sra. } \\
\text { da Conceição }\end{array}$ & Religioso & Macapá/1970 & Arranjo p/ Duas Vozes \\
\hline 101 & Novenário $n$ o 6 & Religioso & Chaves/ 1936 & \\
\hline 102 & Hino à São Sebastião & Religioso & Chaves/1940 & Arranjo para Banda \\
\hline 103 & Dr. Vicente Maués & Hino & Macapá/ 1969 & G.Esc.de Abaetetuba \\
\hline 104 & Frevo & Frevo & Macapá/ 1968 & Arranjo para Banda \\
\hline 105 & Bolero $n=4$ & Bolero & & Arranjo $\mathrm{p} /$ Sax tenor \\
\hline 106 & Eu Quero o Teu Perdão & Bolero & Macapá/ 1960 & \\
\hline 107 & Rancheira p/Acordeon & Rancheira & & \\
\hline 108 & Rancheira $p /$ Trombone & Rancheira & & \\
\hline 109 & Eu Quero Uma Mulher & Samba & Macapá/ 1956 & Arranjo para Banda \\
\hline 110 & Samba & Samba & Macapá/ 1950 & Arranjo p/ Banda \\
\hline 111 & Samba no 1 & Samba & & \\
\hline 112 & Samba $n \div 2$ & Samba & Macapá/ 1953 & \\
\hline 113 & Samba $n=3$ & Samba & Macapá/ 1972 & \\
\hline 114 & Sambinha & Samba & Macapá 1966 & Arranjo $\mathrm{p} /$ Banda \\
\hline 115 & Choro no 1 & Choro & Macapá/ 1974 & \\
\hline 116 & Choro $n \div 5$ & Choro & Macapá/1974 & \\
\hline 117 & Reminiscência & Choro & & Sax Alto- Solo \\
\hline 118 & Andorinha & Canção & Macapá & \\
\hline 119 & Canção à Diretora & Canção & Macapá/1958 & Arranjo p/acordeon \\
\hline 120 & Quadrilha no 1 & Quadrilha & & \\
\hline 121 & Quadrilha $n=2$ & Quadrilha & & \\
\hline 122 & Quadrilha $n=3$ & Quadrilha & & \\
\hline 123 & Quadrilha no 4 & Quadrilha & & \\
\hline 124 & Quadrilha no 5 & Quadrilha & & \\
\hline 125 & São João & Quadrilha & Macapá/1970 & Arranjo p/Acordeon \\
\hline 126 & Quadrilha da Serra & Quadrilha & & \\
\hline 127 & Canção do Amapá & $\begin{array}{l}\text { Marcha } \\
\text { Dobrado }\end{array}$ & Macapá 1944 & $\begin{array}{l}\text { Let. de Joaquim Diniz } \\
\text { Arranjo para Banda }\end{array}$ \\
\hline 128 & Marcha Dobrado N.1 & $\begin{array}{l}\text { Marcha } \\
\text { Dobrado }\end{array}$ & Macapá/1972 & Arranjo para Banda \\
\hline
\end{tabular}




\begin{tabular}{|c|c|c|c|c|}
\hline 129 & Natalina & $\begin{array}{c}\text { Marcha } \\
\text { Grave }\end{array}$ & Soure/1942 & Arranjo para Banda \\
\hline 130 & Despacho & Carimbó & & Clarinete Sib \\
\hline 131 & Não revelarás & Fox canção & & Sax Soprano em Sib \\
\hline
\end{tabular}

Fonte: Uchôa (2003).

Aos 17 anos, Oscar Santos começou a compor para a banda Carlos Gomes e, como estudou praticamente sozinho, criou os seus próprios métodos e técnicas que logo passou a utilizar nas suas aulas de música. Em 1937, o músico saiu de Abaeté e foi para Ilha do Marajó, mais especificamente para as cidades de Soure, Salvaterra, Chaves, Vila Viçosa e Afuá (Uchôa, 2003).

Para Fischer (1984, p. 207), a experiência de um compositor nunca é puramente musical, mas pessoal e social, isto é, condicionada pelo período histórico em que ele vive e que o afeta de muitas maneiras. Os compositores, como Oscar Santos, constituem-se verdadeiros porta-vozes da sociedade, sob os mais diversos estilos musicais (Uchôa, 2003).

Na cidade de Soure, Oscar Santos foi membro do Centro Musical Sourense e compôs vários Dobrados, boa parte das composições servia como forma de homenagear figuras ilustres, como políticos influentes que poderiam, de alguma forma, contribuir com a banda. As bandas foram, no início do século XX, instrumentos de divulgação da música erudita e popular, despertando interesse das gravadoras, e dando uma grande contribuição através da recriação de diversos gêneros musicais, às vezes com caráter quase orquestral (Botelho, 2006, p. 8). Na cidade de Salvaterra, Mestre Oscar era sempre convidado para tocar nas festas e dar aulas de música, em retribuição aos convites compôs um dos seus dobrados em homenagem àquela localidade. Oscar Santos permaneceu em Vila Viçosa até 1939, onde desenvolveu extenso trabalho com Banda de Música.

No início da década de quarenta, Mestre Oscar foi morar em Chaves a convite do Prefeito daquele Município, que o contratou para dar aulas de música e formar uma Banda Musical, para compor essa Banda, convidou seus antigos alunos de Vila Viçosa, que tocavam Saxofone, Trompete, Clarineta e Trombone. As aulas eram ministradas no Centro Musical Chaviense, o qual possuía duas turmas uma para os jovens e outra para os idosos, pois Mestre Oscar, entendia que não tinha idade especifica para aprender a tocar um instrumento musical, bastava apresentar força de vontade. Em 
Chaves, o músico compôs vários Dobrados, entre eles destaca-se o "29 de Dezembro", data de seu nascimento (Uchôa, 2003).

Os intelectuais são indivíduos com a vocação para a arte de representar, seja escrevendo, falando ou ensinando música como fez Oscar Santos. Essa vocação é importante na medida em que é reconhecível publicamente e envolve, ao mesmo tempo, compromisso e risco, ousadia e vulnerabilidade (Said, 2005, p. 27).

Em 1943, Oscar Santos foi para o município de Afuá, formou um conjunto musical e uma Escola de Música. A jornada de Oscar Santos, pelo Marajó, o deixou bastante conhecido pelo trabalho desenvolvido. Recebeu o convite para que o seu conjunto musical tocasse na festa do Círio de Nazaré, em Belém do Pará e no ano seguinte foi convidado para tocar no Círio de Nazaré em Macapá, capital do recém criado Território Federal do Amapá (Uchôa, 2003).

O ponto de partida para o intelectual deve ser o trabalho com indivíduos e grupos nos seus diversos ambientes, sejam eles raciais, culturais, históricos. Tais ambientes devem ser assumidos com seus inúmeros problemas, mas, sobretudo, como ambientes de esperanças e sonhos. O trabalho do intelectual precisa, então, imbuir-se de uma teoria que leve à transformação social, à luta contra as desigualdades sociais, econômicas, políticas e culturais (Giroux, 1997).

No Território Federal do Amapá, Oscar Santos se transformou num grande educador musical e responsável pela Academia de Música Oscar Santos, onde preparou várias gerações de músicos de bandas. Além disso, tornou-se mestre e maestro das primeiras bandas do Amapá e da Orquestra Oscar Santos de onde saíram os primeiros conjuntos musicais do Amapá.

\section{Rede de sociabilidade do Mestre Oscar Santos}

As estruturas de sociabilidade são definidas por Wasserman (2015) como, complexas relações que os intelectuais estabelecem entre si e os locais (espaços físicos) onde eles se reúnem de modo a formarem redes intelectuais que influenciam outros indivíduos. Para Alves (2012, p.118) "a sociabilidade se consolida em práticas estabilizadoras dos mesmos grupos intelectuais, tais como a frequência a determinados lugares, a troca de correspondência, a publicação de textos em certos periódicos, por e- 
xemplo." Sendo que a pesquisadora considera que "a reconstituição dos elos de ligação com pessoas e lugares demonstrou-se indispensável" (Alves, 2012, p.117) para a História intelectual.

A noção de sociabilidade intelectual, segundo Sirinelli (2003), é constituída de duas formas: como redes de sociabilidade que subsidiam o campo intelectual por meio das forças de adesão (amizade, influência, fidelidades) e de exclusão (posições tomadas, cisões), e como "microclimas", que apresentam a conduta específica de um grupo de intelectuais.

As forças de adesão e exclusão, que compõem a primeira compreensão de sociabilidade intelectual, podem ser percebidas, respectivamente, nas semelhanças ideológicas e culturais entre os membros de um grupo de intelectuais, que estabelecem essas afinidades pela convivência no interior do grupo, bem como quando da existência de rivalidades e brigas entre os componentes do grupo. Deste modo, as redes de sociabilidade estão sujeitas às atuações dessas duas forças em seu interior, propiciando permanências ou mudanças no campo intelectual (Sirinelli, 2003).

A segunda forma de entendimento da noção de sociabilidade intelectual para Sirinelli (2003) é apreendida pela constituição de valores afetivos e ideológicos que são aprofundados no interior de um grupo, proporcionando o aparecimento de um "microcosmo intelectual particular", com atributos específicos que caracterizam os intelectuais.

Oscar Santos construiu uma rede de sociabilidade no Território Federal do Amapá, após ter realizado uma apresentação em Macapá com o seu conjunto musical, durante o círio de Nazaré em 1943. Mestre Oscar recebeu o convite do promotor público Hildemar Maia, para tocar no primeiro grito de carnaval, em 20 de janeiro de 1944, mais uma vez a banda de Oscar Santos fez um grande sucesso, a ponto de receber um outro convite do promotor, para tocar na posse do primeiro Governador do Território Federal do Amapá, Janary Gentil Nunes, no dia 25 de janeiro de 1944 (Uchôa, 2003).

O conjunto de Oscar Santos era composto por músicos formados por ele, no município de Afuá, a saber: Afonso Reinaldo, Victor Preto, Victor, o próprio Mestre Oscar e o Mestre Lavico. As apresentações do grupo agradaram bastante as autoridades do Território Federal do Amapá, tanto que receberam uma proposta do Governa- 
dor Janary Nunes, para ministrarem aula de música em Macapá. A proposta foi aceita pelo grupo, apenas o Mestre Lavico retornou para Afuá, desde então, Oscar Santos e seu conjunto começaram a fazer parte das atividades culturais do Território Federal do Amapá.

Em abril de 1944, Oscar Santos conheceu o Sr. Joaquim Gomes Diniz, que era advogado da prefeitura desde 1929 e com a criação do Território Federal do Amapá, foi nomeado Promotor Público Substituto em 1945. Diniz era um admirador das artes e das letras e decidiu fazer uma homenagem ao novo Território Federal, compondo a letra, "Canção do Amapá", e solicitou que o Mestre Oscar fizesse daqueles versos a melodia que se tornaria o Hino do Amapá, por meio de decreto do Governamental no mesmo ano de sua composição em 1944 (Uchôa, 2003).

\section{Quadro 2- Canção do Amapá.}

Eia povo destemido

Deste rincão brasileiro.

Seja sempre teu grito partido

De leal coração altaneiro.

Salve rico o torrão do Amapá

Solo fértil de imensos tesouros

Fonte: Diniz; Santos (1944).
Os teus filhos, alegres, confiam Num futuro repleto de louros. Se o momento chegar algum dia De morrer pelo nosso Brasil Hão de ver deste povo a porfia, Pelejar nestes céus cor de anil.

As músicas compostas por Oscar Santos eram em homenagem a determinados políticos ou figuras influentes, assim como as compostas especificamente para alguma inauguração, ou para homenagear um lugar como, por exemplo, a "Canção do Amapá". Finalizado o evento ou homenagem, a música integrava o repertório habitual da banda.

Oscar Santos se instalou definitivamente em Macapá no ano de 1945, após sua contratação no Governo do Territorial Fiscal de Obras, pois naquela ocasião, não possuía documentos específicos na área de música para exercer o ofício de professor de Música. Em sua residência montou a "Academia Oscar Santos" e dentro de poucos meses formou sua própria banda com alunos de Macapá. Na academia eram ensinados todos os tipos de instrumentos de sopro, percussão, violino e violão, o instrumento que ficou popularizado foi o acordeom. O público da Academia eram os funcionários do governo e os filhos desses funcionários (Uchôa, 2003). 
Por influência de Luís Mendes da Silva (primeiro governador durante o regime militar, nomeado pelo general e presidente Castelo Branco), viajou para o Rio de Janeiro para a Escola Nacional de Música, lá estabeleceu algumas amizades como, por exemplo, o acordeonista e compositor brasileiro, Mario Mascarenhas, responsável pela popularização do acordeom no Brasil por meio das suas aulas e métodos que circularam em todo território nacional, graças ao grande sucesso de Luiz Gonzaga, na década de 1950.

Dom Pedro II fundou no século XIX, o Conservatório de Música em 1841, o qual se tornou em 1848 o Instituto Nacional de Música, atual Escola de Música da UFRJ. Quando o instituto encerrou suas atividades como instituição autônoma e foi incorporado à Universidade do Rio de Janeiro em 1937, tornou-se a Escola Nacional de Música, responsável pela formação de várias gerações de músicos no Brasil (Haas, 1991).

Mestre Oscar se filiou à academia de música Mario Mascarenhas e assim conseguiu receber em Macapá todos os livros e instrumentos musicais que necessitava. Além de formar bandas, Mestre Oscar formou também pequenos grupos para a participação de festas em escolas, carnavais e nos programas da Rádio difusora, formou o grupo feminino de acordeons e percussão e por onde tocavam faziam grande sucesso. Mestre Oscar incentivara seus alunos a tocarem em outras localidades, levando a música a vários municípios, e principalmente em alguns interiores do Pará e Amapá, os alunos tocavam gêneros variados em especial a música popular brasileira e, eram estimulados a aprender as músicas de forma auditiva e visual, ou seja, tirar música de ouvido e ler a partitura, esses eram quesitos de um de seus métodos de ensino (Uchôa). 
Fotografia 2: Conjunto feminino de acordeons, juntamente com Mestre Oscar Santos.

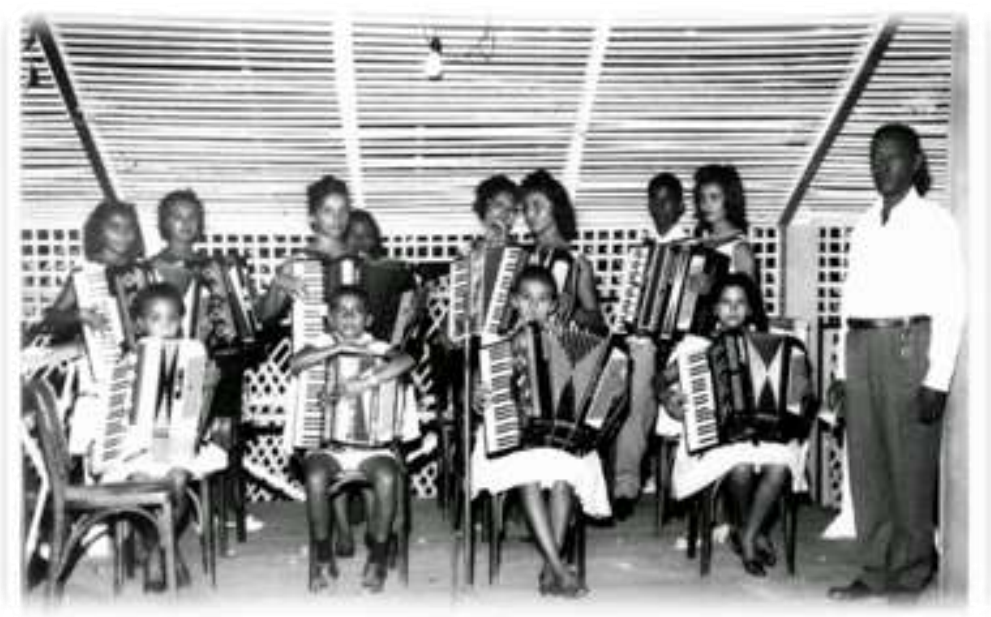

Fonte: Site Porta Retrato AP (2018).

A participação das mulheres no fazer musical é algo marcante na carreira de Oscar Santos, haja vista que as bandas e conjuntos musicais no século XX apresentavam um caráter mais masculino por possuírem uma estrutura diferenciada e devido à força dos metais e dos instrumentos de percussão. Esse acesso das mulheres às bandas musicais pode ser considerado um grande passo na conquista por um lugar de destaque na sociedade amapaense. Além disso, esse fato demonstra que Mestre Oscar era um intelectual a frente do seu tempo.

A música tem a capacidade de transformar o que é singular em coletivo, fazendo com

que os processos sociais, seus valores e significações se realizem. Assim o processo da criatividade do músico, como um produto histórico-social, está sempre inserido no tempo/espaço, em condições objetivas do contexto, mas sempre mediado por um processo intersubjetivo (Maheirie, 2003).

Em 25 de janeiro de 1952, Mestre Oscar Santos participou da programação da Solene de Inauguração do Conservatório Amapaense de Música, como integrante do primeiro Corpo Docente, responsável pelas disciplinas Teoria Musical, Solfejo e Harmonia Elementar, a convite do diretor Altino Pimenta. Mas, Oscar Santos, permaneceu por pouco tempo, pois não se adaptou às normas do Conservatório e solicitou sua demissão do cargo, preferindo dar aulas em sua Academia, a qual crescia a cada dia, devido à variedade de instrumentos que ensinava (Uchôa, 2003).

Segundo Gramsci (1991) os intelectuais orgânicos nascem da necessidade das 
próprias classes subalternas de se organizarem e expressarem seus anseios e visão de mundo, já que diferentemente do tipo de intelectual tradicional, que exerce "o monopólio do saber na sociedade, [...] o intelectual orgânico, deve portar-se como um organizador da vontade coletiva, um construtor da nova hegemonia, um 'persuasor permanente', que necessita garantir sua inserção ativa e contínua na vida prática".

Vieira (1987) afirma que o intelectual deve se colocar "acima das circunstâncias", pois considera que a vida circundante não possui atrativos suficientes para o seu "notório saber". Os "intelectuais, recusam-se a 'sujar as mãos' com tarefas aparentemente simples como a de socializar um conhecimento erudito que, diga-se de passagem, adquiriram às custas de rigorosos estudos e incomum esforço de busca de uma 'nova verdade', ainda que está nem sempre fosse a de seu tempo e lugar" (Vieira, 1987, p.67-68).

Fotografia 3: Alunos da Academia Mestre Oscar Santos.
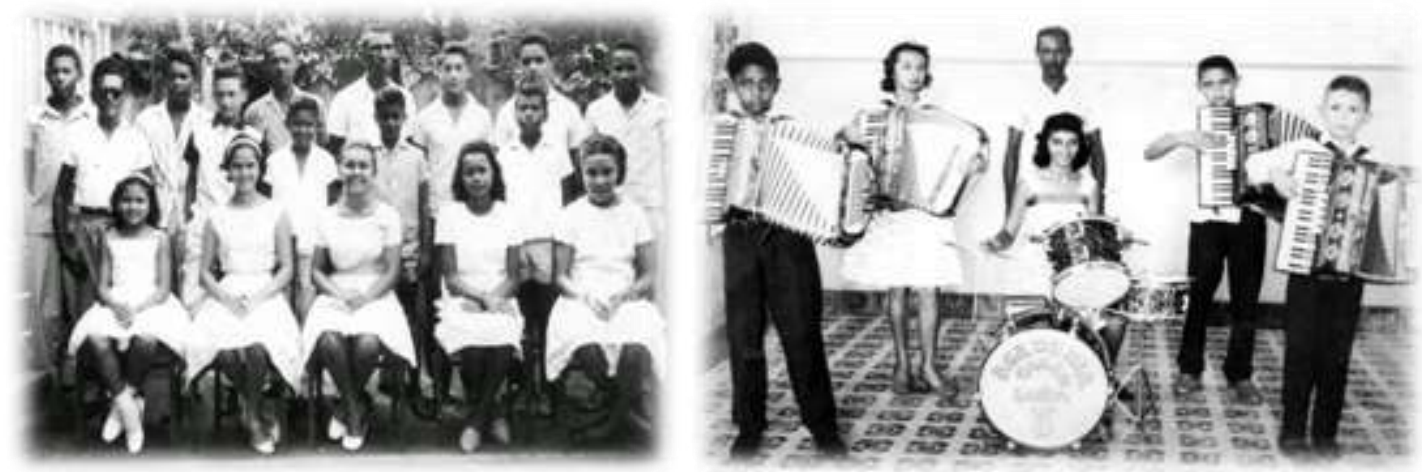

Fonte: Site Porta Retrato AP (2018).

Quanto à musicalização de seus alunos, o Mestre Oscar utilizava para a parte teórica primeiramente o $A B C$ Musical e depois o método bonna para o aprendizado da leitura, do solfejo e a severa cobrança da regência. O método bonna é utilizado nas práticas de banda nos conservatórios e escolas de música, tanto para instrumentos musicais de sopro, quanto no auxílio da divisão métrica, leitura de partitura e estudo de diversos ritmos (Uchôa, 2003).

As bandas ofereciam a oportunidade de uma comunidade aprender a tocar instrumentos e teorias musicais, preparando o músico para ser profissional numa banda militar, tocar em orquestras ou ser músico em qualquer conjunto musical. Essa banda está diretamente em contato com a comunidade, enquanto exerce o papel fun- 
damental de acolher crianças, jovens e adultos interessados em aprender um instrumento (Gomes, 2008).

Quanto aos métodos de avaliação, Mestre Oscar cobrava integralmente o $A B C$ musical, a avaliação teórica era feita oralmente, na qual os alunos só avançavam se soubessem responder as questões de maneira firme e clara, a prática instrumental só começara a partir do domínio do solfejo e da leitura rítmica. Em relação aos alunos dos instrumentos de sopros, as aulas eram ministradas com exercícios criados por Oscar Santos, eram métodos baseados nas dificuldades dos alunos e assim estipulados por nível, tocavam a escala na tonalidade que estava o instrumento. Aos alunos de acordeom eram destinados os métodos Mascarenhas e Alencar Terra que era um compositor, instrumentista e acordeonista de música popular brasileira (Uchôa, 2003).

Sirinelli (2003) destaca que um intelectual se define sempre por referência a um legado (como intermediação, ou mesmo como ruptura), por isso, os estudos no campo da História Intelectual, não devem desconsiderar a responsabilidade do intelectual, atentando para seus erros e acertos, para as ideias avançadas e também retrógradas. Para Said $(2003$, p.38) a atividade do intelectual na sociedade pode assumir "muitas frentes, muitos lugares, muitos estilos, e que mantêm em uso tanto o sentido de oposição quanto o sentido de participação engajada".

Assim, "apesar de ninguém poder saber tudo, deve ser possível discernir os elementos de uma disputa ou tensão ou problema próximo de nós, que pode ser dialeticamente elucidado, e também sentir que outras pessoas têm um interesse semelhante e trabalhar num projeto conjunto" (Said, 2003, p.38) e o intelectual pode ser o potencializador.

Em 09 de novembro de 1962, Oscar Santos recebeu certificado de habilitação profissional, fornecido pela Ordem dos Músicos do Brasil, no Rio de Janeiro. Em seguida tornou-se o primeiro Presidente da Ordem dos Músicos do Brasil, Seção Amapá, no período de 1962 a 1970. Em seguida, foi convidado pela secretária de educação, professora Aracy Mont'Alverne, para ser professor na escola Industrial de Macapá.

Sendo bem recebido pelo diretor da escola industrial, professor Antenor Epifânio Martins, Mestre Oscar o homenageou com a obra "Dobrado Epifânio Martins", e homenageou os alunos da escola, com o Dobrado "Os Bonequinhos", porque os alunos se uniformizavam todos de azul, por esse motivo, receberam o apelido por vários anos 
de "Bonequinhos de Anil" (Uchôa, 2003).

No ano de 1965, Mestre Oscar voltou ao Rio de Janeiro para obtenção de mais um diploma para compor no seu currículo de músico, o Conservatório de Música do Rio de Janeiro o diplomou como técnico em Teoria Musical, após a submissão de um extenso exame de avaliação. Ainda em 1965, no dia 19 de abril, a escola industrial tornou-se ginásio de Macapá.

As bandas sempre exerceram importante papel de escola formadora de músicos em todo o país. Hoje, um bom número de instrumentistas profissionais no Brasil aprendeu suas primeiras notas musicais numa banda civil. Além disso, há uma tradição e uma memória que são transmitidas de geração em geração no espaço social da banda, entre os músicos de diferentes faixas etárias, o que tem possibilitado a permanência desta manifestação na cultura brasileira (Gomes, 2008).

Oscar Santos, também ministrou aulas de educação musical no Instituto de Educação do Território do Amapá (IETA), no período de 1965 a 1972, onde era o professor responsável pela disciplina componente curricular pedagógico. Em fevereiro de 1971, Mestre Oscar fundou a Banda de Música do Serviço Social da Indústria- SESI, e como de costume, os alunos aprendiam em pouco tempo já estavam aptos para tocarem na banda e participarem de desfiles da semana da pátria e outras festas importantes do Território Federal do Amapá (UCHÔA, 2003).

Mestre Oscar faleceu no dia 20 de março de 1976, na cerimônia de seu sepultamento foi homenageado pela Banda do Ginásio de Macapá que passou a se chamar "Banda Oscar Santos".

\section{Noção de geração de Oscar Santos}

Quanto à noção de geração, de acordo com Gomes (1999), é um grupo que constrói uma memória comum, referida a um "tempo" e a "acontecimentos" que conformaram uma certa maneira de experimentar, no caso, a vida intelectual. Para Wasserman (2015, p. 71), “a geração não se refere tanto aos nascidos em uma mesma época, mas está relacionada com marcos, episódios e processos históricos vividos por indivíduos de diferentes idades e cujas vidas foram impactadas por essas ocorrências", ou seja, tal conceito "depende de um conjunto de afinidades, de sensibilidades 
comuns, herdadas e vivenciadas, capazes de condicionar o sentimento de partilha de um mesmo destino" (SILVA, 2003, p.23).

A noção de geração para Silva, (2003, p.24), pode se revelar um instrumento conceitual importante para desvendar a história das representações coletivas, ou seja, a paisagem intelectual e moral de uma época, os sistemas de valores e as sensibilidades coletivas". Nora (1997) concebe a noção de geração indissociável dos lugares de memória, pois é pertinente falar de memória geracional para as situações de maior "tomada de consciência" de pertencimento de geração.

Os lugares onde ela [a memória] se condensa e se exprime têm em comum o fato de serem lugares comuns, centros de participação coletiva, mas passíveis de uma imediata apropriação pessoal... a memória geracional advém de uma sociabilidade de conjunto histórico e coletivo para se interiorizar até as profundezas viscerais e inconscientes que comandam as escolhas vitais e as fidelidades reflexas. $O$ 'eu' é ao mesmo tempo um 'nós'" (NORA, 1997, p. 3)

Nesse sentido, este trabalho não trata de "grandes intelectuais", ao contrário, ele faz o movimento indicado por Sirinelli $(2003$, p. 246) de "descermos até o estrato intermediário dos intelectuais de menor notoriedade, mas que tiveram importância enquanto viveram", no caso desse estudo o intelectual amazônico, Mestre Oscar Santos, que construiu um legado no que se refere ao ensino de música no Território Federal do Amapá no período de 1944 a 1976.

No meio intelectual, os processos de transmissão cultural são essenciais, o que explica em última análise a posição que um intelectual ocupa dentro de sua própria corporação ou estamento visto que "um intelectual se define sempre por referência a uma herança, como legatário ou como filho pródigo (Sirinelli, 2003, p.255). Mestre Oscar construiu seu projeto intelectual na troca de experiências e amizades com outros intelectuais, músicos e compositores, como por exemplo, Bruno de Menezes, José Plácido Gonçalves, Mario Mascarenhas e Altamiro Carrilho.

Oscar Santos conheceu na década de 1930, em Belém do Pará, o poeta Bruno de Menezes (1893-1963), reconhecido enquanto introdutor do Modernismo na Amazônia, obteve destaque no cenário cultural desde a primeira metade do século XX, não apenas pela qualidade de suas obras literárias, mas também por sua liderança em gru- 
pos de intelectuais e pelo seu engajamento político-social. Bruno de Menezes fundou em 1923, a revista Belém Nova, que abrigou trabalhos tanto dos modernistas como de antigos companheiros. Em 30 de maio de 1944 tornou-se membro da Academia Paraense de Letras, onde chegou a ser presidente. Em 1954, tornou-se membro do Instituto Histórico e Geográfico do Pará e da Comissão Paraense de Folclore (Wanzeler, 2006).

Em 1935, Bruno de Menezes escreveu a letra do "Hino Mater Puríssima" em homenagem a Nossa Senhora da Conceição e pediu a Oscar Santos que fizesse uma melodia, surgindo assim a parceria e amizade entre esses dois intelectuais amazônicos. Todo o mês de dezembro, durante as festividades da padroeira de Abaetetuba, ele é cantado em todas as procissões, missas e encontros que antecedem o Círio.

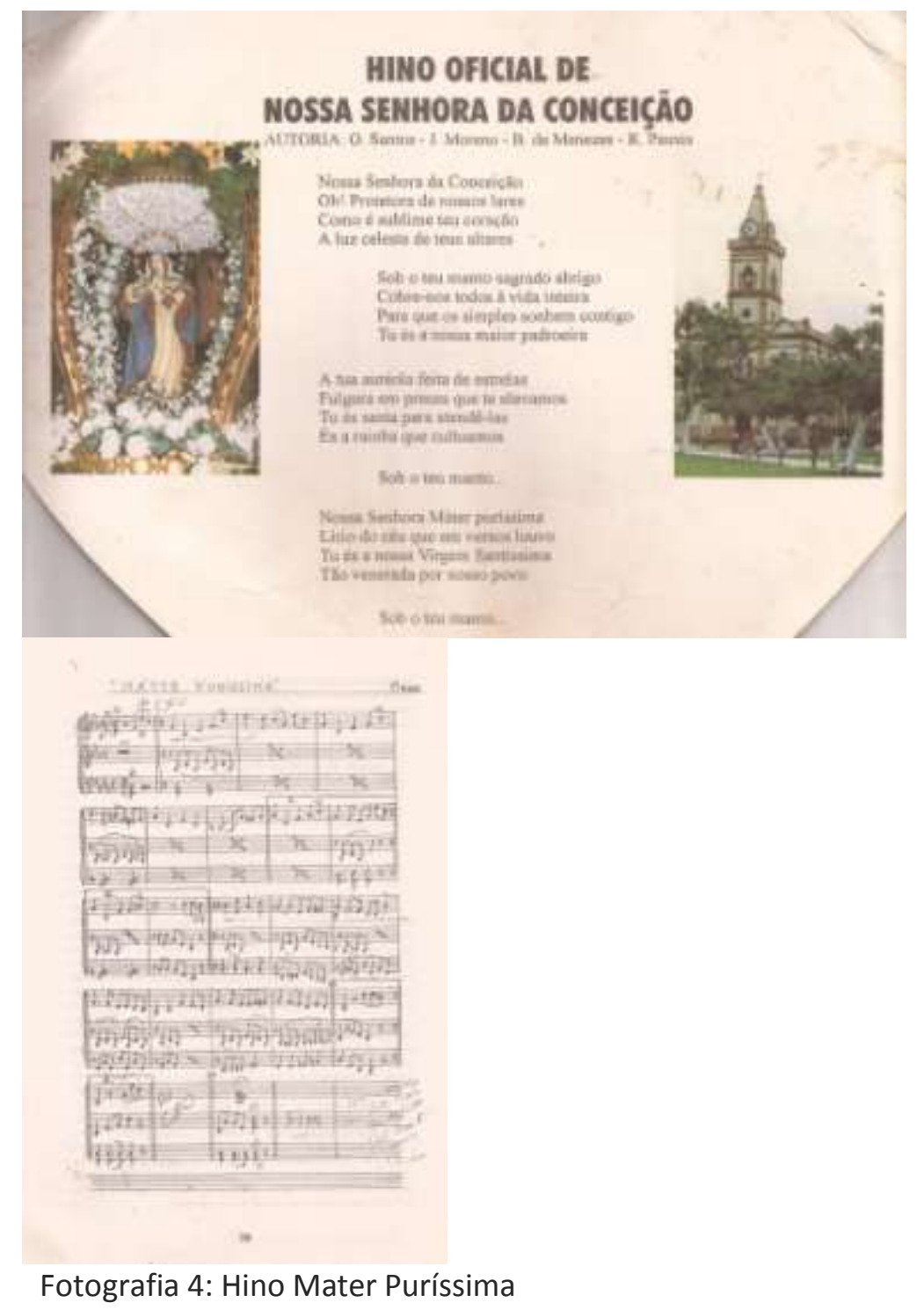


Fonte: Rocha (2018).

Os antigos músicos, em sua maioria, eram quem tomavam iniciativa, consciente ou inconscientemente, da organização das festas de santos, especialmente no tempo em que Abaetetuba praticamente não possuía um pároco residente no município e eram as comunidades dos diversos locais que tomavam a iniciativa dos festejos dos santos na forma das antigas devoções dos santos, com as Folias de Santos de Abaetetuba. Muitos artistas, músicos e compositores, como Bruno de Menezes e Oscar Santos faziam questão de dar sua contribuição a Nossa Senhora da Conceição ou outros eventos católicos festivos (Monte Serrat, 1990).

Oscar Santos formou uma banda de música em Igarapé-Miri, onde conheceu o músico José Plácido Gonçalves, surgindo daí uma grande amizade, os dois formaram um Conjunto Musical e passaram ensinamentos aos jovens daquele Município. José Plácido Gonçalves, exímio tocador de flauta, teve vários alunos, dentre eles seu filho Pinduca (considerado o Rei do Carimbó do Brasil), e sua bisneta Dona Onete (executora de uma forma particular de executar o carimbó, batizada por ela de carimbó chamegado) os quais transmitiu seus ensinamentos (Moraes, 2014).

No ano de 1958, Oscar Santos recebeu em Macapá, o amigo e professor Mário Mascarenhas, popularmente conhecido como o "Rei do Acordeom", ajudou a difundir ainda mais o instrumento, desenvolvendo um método com ensinamentos que facilitavam sua execução. O método continha desde músicas folclóricas a peças de compositores estrangeiros e brasileiros, assim como exercícios técnicos, a saber: escalas, arpejos, formação de acordes e fórmulas rítmicas de gêneros musicais variados (Uchôa, 2003). 


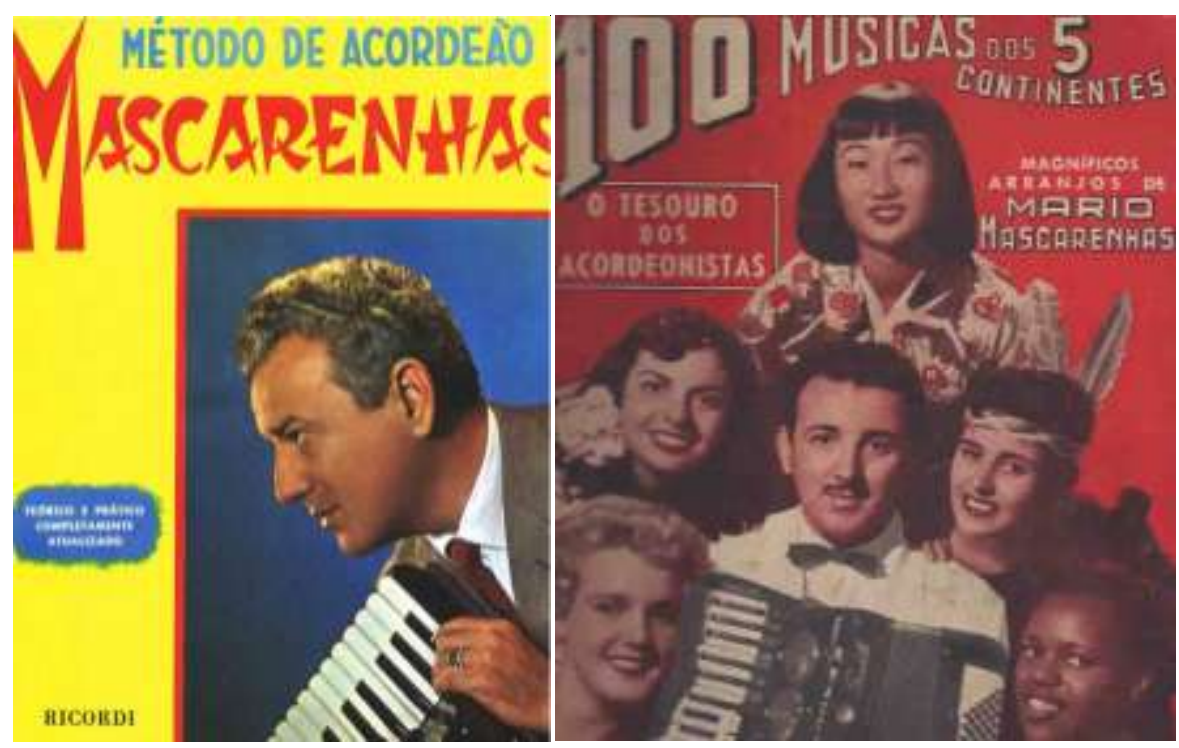

Fotografia 5: Livros de Ensino do Método Mascarenhas.

Fonte: Araújo (2010).

Até o ano de 1956, sua publicação chegou a atingir quase duzentas mil cópias vendidas, o que acabou favorecendo sua 25a edição. Mário Mascarenhas foi também responsável pela organização de 120 academias empenhadas no ensino do acordeom no Brasil, dentre elas a Academia Oscar Santos no Território Federal do Amapá. A principal Academia de Mascarenhas situava-se no Rio de Janeiro e era considerada a "academia modelo" entre todas as existentes (Araújo, 2010).

Os alunos de Mestre Oscar, durante a vista de Mascarenhas em Macapá, fizeram um grande recital de acordeom para mostrar o que tinham aprendido com os seus métodos. Mário Mascarenhas incentivou e convidou Oscar Santos a fazer um curso no Rio de Janeiro que o habilitasse como professor de música. Em 1959, após um curso intensivo de três meses na Academia Brasileira de Arte do Rio de Janeiro, Oscar Santos conseguiu o diploma de Harmonia, Teoria e Solfejo (Uchôa, 2003).

O flautista Altamiro Carrilho foi uma grande referência para os flautistas brasileiros e outros instrumentistas, dentre eles o Mestre Oscar Santos. A discografia de Altamiro Carrilho é extensa, tendo gravado como solista e/ou flautista acompanhador. Sarmento $(2005$, p. 68$)$ registra que o músico "[...] decolou rumo ao sucesso, com uma carreira brilhante somando mais de 130 gravações em discos e CDs". Uma grande parte dessas gravações aconteceu graças à criação da Bandinha do Altamiro Carrilho, no ano de 1955. O grupo era formado por nove músicos e seu repertório era bastante variado, composto por valsas, polcas, maxixes, dobrados, marchas de carnaval e arran- 
jos de vários outros estilos.

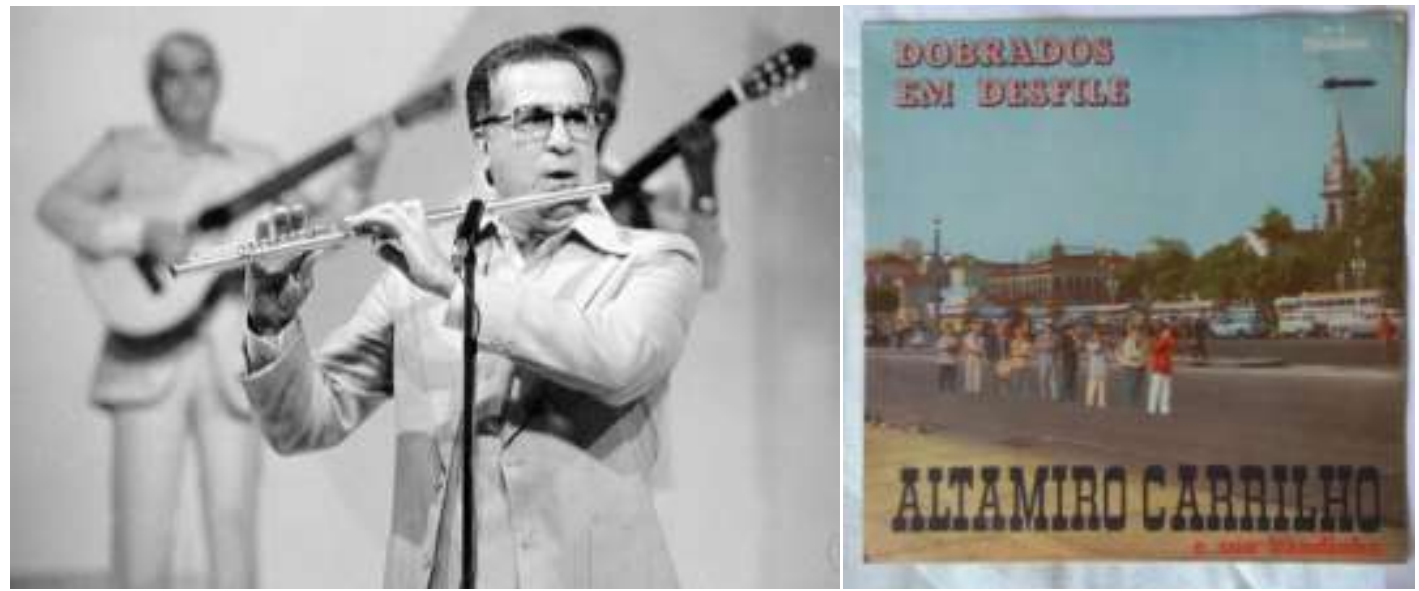

Fotografia 6: Músico Altamiro Carrilho Fonte: Pereira (2016).

O músico foi também compositor, não apenas de choros, mas de uma diversidade de gêneros, incluindo sambas, marchas, modinhas, canções românticas, etc. Altamiro foi um "compositor de versatilidade extraordinária, compôs cerca de 200 músicas dos mais variados ritmos e estilos". Duas características a se destacar do professor Altamiro: a primeira é que, numa espécie de herança do seu primeiro professor, que não Ihe cobrava as aulas por não ter condições de pagar, Carrilho também dava aulas gratuitas aos alunos carentes; a segunda característica é o fato de o flautista fazer distinção dos alunos pelo talento: aqueles que obtinham bons resultados até ganhavam flauta como presente; já os de menor talento eram desencorajados pelo mestre (Pereira, 2016).

No final da década de cinquenta, a cidade de Macapá foi surpreendida ao ouvir o Dobrado 15, de autoria do Mestre Oscar, gravado por Altamiro Carrilho e sua Bandinha, pela Som Indústria e Comércio S/A, Discos Copacabana, com o título, "Dobrados em Desfile". No disco, não saiu o nome do autor, mas sim a palavra Macapá, os jornais locais divulgaram bastante o ocorrido e anos mais tarde, Altamiro Carrilho descobriu Mestre Oscar e o parabenizou pela autoria do Dobrado. Outra obra sua executada na Rádio Tupi por Altamiro Carrilho foi o Dobrado I Centenário de Macapá, naquela época foi divulgado pelos jornais que a obra seria gravada em Discos Copacabana, porém, isso não aconteceu.

Como se pode ver a rede de sociabilidade de Oscar Santos é formada a partir de pessoas com as quais ele trocou conhecimento, no âmbito do ensino de música, prin- 
cipalmente no movimento de formação de bandas e conjuntos musicais e sempre buscando a sua qualificação profissional enquanto professor de música.

Mestre Oscar pode ser considerado um intelectual, porque Intelectual não é sinônimo de cientista ou acadêmico. Intelectual é, mais propriamente, aquele que faz da tarefa de transformar informações em conhecimentos uma prática sistemática, permanente e cotidiana. É aquele que se esmera em manter viva a curiosidade sobre o mundo à sua volta; aquele que observa as várias faces do mesmo fenômeno, as informações novas, contraditórias e complementares; aquele que apura o olhar; aquele que não se contenta com uma só interpretação, nem se limita a repetir o que já disseram (Silva, 2007, p. 6).

Said (2005), ao tomar como pressuposto o conceito gramsciano, argumenta que os professores seriam os intelectuais tradicionais. Said pontua que intelectuais todos os sujeitos são, mas a função só consegue ser exercida por algumas pessoas. Neste sentido, defende que os professores seriam os intelectuais tradicionais porque estariam, geração após geração, fazendo a mesma coisa: ensinando as mais jovens.

Oscar Santos, antes de morrer, teve tempo de ver os frutos de seu esforço com o ensino de música no Território Federal do Amapá. As primeiras bandas marciais das escolas públicas de Macapá foram organizadas por seus alunos, alguns deles ingressaram na banda de música da Polícia Militar e fizeram carreira, como é o caso do José do Carmo Freitas (Nambu), que chegou a regente. Outros ingressaram no Exército e na Aeronáutica. É o caso do subtenente Marinho, sobrinho do mestre, trompetista que se dedica até hoje a fazer arranjos para bandas de músicas e transcrições de melodias da música popular. Também há aqueles que atualmente são professores de música, Brasil afora, como o professor Biraelson Corrêa, Lúcia Uchôa, que atuam na Escola de Música da Universidade Federal do Pará e Joaquim França, regente da Orquestra Filarmônica de Brasília.

\section{Considerações Finais}

Este estudo teve como objetivo analisar a atuação do Mestre Oscar Santos no ensino de música no Território Federal do Amapá, no século XX e a sua constituição enquanto um intelectual amazônico, onde apresentamos seus itinerários de formação, 
as redes de sociabilidade e a sua geração.

Mestre Oscar, paraense de Abaetetuba, nasceu em uma família de músicos e se tornou professor e intelectual no contexto amazônico no que se refere ao ensino de música e formação de bandas em vários municípios do Pará e tendo consolidado sua atuação profissional no Território Federal do Amapá, a partir de 1944. Além de professor era compositor, escreveu mais de 130 arranjos musicais, principalmente dobrados em homenagem a lugares, santos, pessoas comuns e autoridades locais.

No Território Federal Amapá, Oscar Santos se transformou num grande educador musical e se tornou o responsável pela Academia de Música Oscar Santos, onde preparou várias gerações de músicos de bandas; além disso, se tornou mestre e maestro das primeiras bandas do Amapá. Da Orquestra Oscar Santos saíram os primeiros conjuntos musicais do Amapá. Mestre Oscar construiu seu projeto intelectual na troca de experiências e amizades com grandes personalidades da música e cultura da sua geração, como por exemplo, Bruno de Menezes, José Plácido Gonçalves, Mario Mascarenhas e Altamiro Carrilho.

Mestre Oscar Santos contribuiu também na formação de uma nova geração de músicos que seguiram carreira militar como músicos. E outros que seguiram a carreira docente, e atuam em instituições renomadas de ensino de música pelo Brasil a fora.

\section{Referências}

ALVES, Cláudia. Jean-François Sirinelli e o político como terreno da história cultural. In: LOPES, Elaine Marta Teixeira; FARIA FILHO, Luciano Mendes. (Org.). Pensadores sociais e a história da educação. Belo Horizonte: Autêntica Editora, 2012.

ARAUJO, Joana de Cássia Santos. A sanfona na cena musical carioca. Dissertação (Mestrado em Música) - Universidade Federal do Estado do Rio de Janeiro, Rio de Janeiro, 2010.

ARAÚJO, Sônia Maria da Silva. Um estudo comparado do pensamento educacional na América Latina - Brasil e Venezuela (1819-1928). (Relatório de Pesquisa). Belém, 2011.

BOTELHO, Marcos. A Sociedade Musical Beneficente Euterpe Friburguense: Um estudo histórico-social. 2006. 100f. Dissertação (Mestrado em Música) - Escola de Música, Universidade Federal do Rio de Janeiro - UFRJ, Rio de Janeiro.

DINIZ, Joaquim Gomes; SANTOS, Oscar. Canção do Amapá. Território Federal do Ama- 
pá. Macapá, 1944.

ELIAS, Norbert. Mozart, sociologia de um gênio. Rio de Janeiro, Jorge Zahar, 1995.

FALCON, F. História das ideias. In: CARDOSO, Ciro Flamarion; VAINFAS, Ronaldo (Orgs.). Domínios da história: ensaios de teoria e metodologia. Rio de Janeiro: Campus, 1997. p. 139-188.

FISCHER, Ernest. A necessidade da arte. 5. ed. Rio de Janeiro: Zahar; Imprensa Nacional, Casa da Moeda, 1984.

GIROUX, Henry. Os professores como intelectuais: rumo a uma pedagogia crítica da aprendizagem. Tradução Daniel Bueno. Porto Alegre - RS: ArtMed, 1997.

GIROUX, Henry. Escola crítica e política cultural. 3. ed. São Paulo: Autores Associados, 1992.

GOMES, Ângela de Castro. Essa gente do Rio: modernismo e nacionalismo. Rio de Janeiro: Fundação Getúlio Vargas, 1999.

GOMES, Karina Barra. E hoje, quem é que vê a banda passar? Um estudo de práticas e políticas culturais a partir do caso das bandas civis centenárias em campos dos Goytacazes. Dissertação Mestrado, Universidade Estadual Fluminense. Campos dos Goytacazes, 2008.

GONZALEZ, Horácio. O que são os intelectuais. São Paulo: Brasiliense, 2001.

GRAMSCl, Antonio. Caderno 12 (1932) - Apontamentos e Notas Dispersas para um Grupo

de Ensaios sobre a História dos Intelectuais. In: Cadernos do Cárcere. Tradução de Carlos

Nelson Coutinho et. all. 3. ed. Rio de Janeiro: Civilização Brasileira, 2004. p. 15-53.

GRAMSCl, Antônio. Os intelectuais e a organização da cultura. Rio de Janeiro: Civilização Brasileira, 1991.

HAAS, Eliane. A arte de tocar piano. Dissertação de Mestrado, Centro de PósGraduação, Pesquisa e Extensão do Conservatório Brasileiro de Música. Rio de Janeiro, 1991.

MAHEIRIE, K. Processo de criação no fazer musical: uma objetivação da subjetividade, a partir dos trabalhos de Sartre e Vygotsky. Psicologia em Estudo, Maringá, v. 8, n. 2, p. 147-153, 2003.

MONTE SERRAT, Maria. Verdades, Atos e Fatos Ainda não ditos. Belém: Arajá,1990.

PEREIRA, Marcelo das Dores. Procedimento ritmico-melodico na performace de Altamiro Carrilho. Um estudo de caso aplicado ao ensino de música. Dissertação de Mestra- 
do, UFMG, Belo Horizonte, 2016.

LOPES, Marcos Antônio. Grandes nomes da História Intelectual. São Paulo: Contexto, 2003.

MORAES, Patrich Depailler Ferreira. O feitiço Caboclo de Dona Onete: um olhar etnomusicológico sobre o carimbó chamegado, de Igarapé-Miri à Belém. Dissertação de Mestrado, Programa de Pós-Graduação em Artes, UFPA, Belém, 2014.

RÉMOND, René. Por uma história política. 2aㅡ ed. Rio de Janeiro: FGV, 2003.

ROCHA, Ademir. A fé católica como influência na musicalidade de Abaetetuba através dos anos. Disponível em: <http://ademirhelenorocha.blogspot.com/2012/08/a-fe-cato lica-como-influencia-na.html>. 04 Set. 2018.

SAID, Edward. Cultura e política. São Paulo: Boitempo editorial, 2003.

SAID, Edward. Representações do intelectual: as Conferências Reith de 1993. São Paulo: Companhia das Letras, 2005.

SARMENTO, Luciano Cândido e. Altamiro Carrilho: Flautista e Mestre do Choro. 2005. 154 f. Dissertação (Mestrado) - Curso de Mestrado em Música, Universidade Federal da Bahia, Salvador, 2005.

SILVA, Helenice Rodrigues da. Fragmentos da História Intelectual: entre questionamentos e perspectivas. São Paulo: Papirus, 2002.

SILVA, Helenice Rodrigues da. A História intelectual em questão. In: LOPES, Marcos Antônio. Grandes nomes da História Intelectual. São Paulo: Contexto, 2003. p.15-39.

SILVA, Francisco Lucas. A natureza me disse. Natal: Flecha do Tempo, 2007. Disponível em<http://www.educampoparaense.com.br/publicacao/a-natureza-me-disse>. Acesso em: 09 agos. 2018.

SIRINELLI, Jean François. Os Intelectuais. In: REMOND, René. Por uma História Política. Rio de Janeiro, Fundação Getúlio Vargas, 2003.

SIRINELLI, Jean-François. As elites culturais. In: RIOUX, J. P.; SIRINELLI, J. F. Para uma história cultural. Lisboa, Editora Estampa, 1998.

UCHÔA, Lúcia. As bandas de música nos estados do Pará e Amapá: vida musical do Mestre Oscar Santos. Dissertação. Mestrado em Musicologia. Escola de Comunicações e Artes. Universidade de São Paulo. São Paulo, 2003.

VIEIRA, Carlos Eduardo. Intelligentsia e intelectuais: sentidos, conceitos e possibilidades para a história intelectual. Revista Brasileira de História da Educação. v.8, n.16 jan./abr. 2008. 
VIEIRA, Carlos Eduardo. O Movimento pela Escola Nova no Paraná: trajetória e ideias educativas de Erasmo Pilotto. Educar em Revista, Curitiba - PR, v. 1, n. 18, p. 53-74, jul., 2001.

VIEIRA, Sofia Lerche. A educação e o intelectual acima das circunstâncias. Cadernos de Pesquisa (Fundação Carlos Chagas), São Paulo, v.60, p. 66-69, 1987.

WANZELER, Rodrigo de Souza. Bruno de Menezes: fragmentos de memórias (des)construindo histórias de vida de um literato-etnógrafo. XIII Encontro Nacional de História Oral. Rio Grande do Sul, 2006.

WASSERMAN, Claudia. História intelectual: origem e abordagens. Tempos Históricos. Vol. 19, 10 sem/2015. p.63-79.

Artigo recebido em setembro de 2018 e aceito em novembro de 2018. 